\title{
SOPHISTICATION IN THE USE OF BUDGETING PRACTICES
}

\author{
Ricardo Suave ${ }^{1}$ \\ Rogério João Lunkes ${ }^{2}$ \\ Sérgio Murilo Petri ${ }^{3}$ \\ Fabricia Silva da Rosa ${ }^{4}$
}

\begin{abstract}
Previous studies regarding the budgeting practices topic seek to conduct surveys about what budgeting practices are used by companies, but there is no initiative to indicate which of them can be best suited. This paper aims to construct a model to assess the level of sophistication of the budgeting practices of companies. To build the model, we used MCDA-C (Multicriteria Decision Aiding - Constructivist) methodology. We developed the model with the use of a value function for conversion of the scale, the method of the Direct Score was used. The model enables the demonstration of the sophistication level in the use of surveyed budgeting practices as well as for comparisons between research in different countries and industries. Using an instrument from another area of knowledge, the model contributes to measure the sophistication level of budgeting practices used.
\end{abstract}

Keywords: Budgeting. Budgeting practices. Model. Level of sophistication. MCDA-C.

\footnotetext{
- Paper presented at the AAA Annual Metting (Atlanta - 2014).

'E-mail: ricardosuave@usp.br - University of São Paulo

${ }^{2}$ E-mail: rogeriolunkes@hotmail.com - Federal University of Santa Catarina

${ }^{3}$ E-mail: smpetri@gmail.com - Federal University of Santa Catarina

${ }^{4}$ E-mail: fabriciasrosa@hotmail.com - Federal University of Santa Catarina 


\section{INTRODUCTION}

$\mathrm{B}$ udgeting has many uses, such as assistance for profitability increase, communication of goals and operations coordination (Abratt, Beffon \& Ford, 1994; Hansen \& Van der Stede, 2004; Joshi, Al-Mudhaki \& Bremser, 2003). According to Simons (1990), budgeting has recognized importance as a management control function, which ensures the achievement of the organization's goals.

Although the budgeting is considered the cornerstone of the management control process and its widespread use, there are some problems related to this instrument (Hansen, Otley \& Van der Stede, 2003). Among the criticisms in the literature directed to the budgeting, Libby and Lindsay (2010) list some of them, for instance, the budgeting is originally flawed, too much time consuming and generates dysfunctional behaviors. For this reason, research groups have developed modifications to the instrument, like the Activity Based Budgeting (ABB) and the Beyond Budgeting (BB) (Hansen et al., 2003).

Even after criticism and the emergence of new management techniques such as Balanced Scorecard, activity-based techniques and strategic management accounting, it seems that the budgeting is still widely used by enterprises (Abdel-Kader \& Luther, 2006). In addition, research results show that most companies do not plan abandon the budgeting (Libby \& Lindsay, 2010; Umapathy, 1987).

One of the possible ways in attempting to clarify this discussion is regarding the way that companies employ the budgeting, that is, the practices used. There are many studies in the literature which examine the practices adopted by companies, such as the use of manual and budgeting committee, the time spent in preparation and also the time horizon that is intended. In addition, some of these studies aim to understand the reasons in which companies use budgeting, motivational issues and other aspects regarding control and performance evaluation (Almeida, Machado, Raifur \& Nogueira, 2009; Castro, Souza, Santos \& Lunkes, 2012; Cress \& Pettijohn, 1985; Hansen \& Van der Stede, 2004; Jones, 1998; Jones, 2008a; Joshi et al., 2003; Pereira \& Espejo, 2012; Predengarst, West \& Shi, 2006; Schmidgall \& Ninemeier, 1986; Steed \& Gu, 2009; Uyar \& Bilgin, 2011).

These initiatives are evidence that there is an effort by the academy to investigate what happens in companies, demonstrate directions in the use of certain practices and make suggestions for improvements. However, among the research related to the subject, there are no models that can evaluate the practices of companies and, consequently, the level of sophistication of the budgeting.

Studies that encompass the use of constructivist methods constitute an alternative for developing evaluation models. The constructivist methodology provides decision support to identify objectives to be evaluated and measured, besides generating contributions for improvements. According to Ensslin, Montibeler Neto and Noronha (2001), the features evaluations originate the performance of each one and the results are divided into three groups: compromising, competitive or excellence. Previous studies in the literature have used this methodology to assess other issues (Bortoluzzi, Ensslin \& Ensslin, 2011; Rosa, Ensslin, Ensslin \& Lunkes, 2012; Tasca, Ensslin \& Ensslin, 2012).

From the context presented, emerges the following question of research: What is the sophistication level of budgeting practices adopted by companies? Thus, the present study aims, from budgeting practices contained in the literature, to construct a model to assess the level of sophistication of the budgeting practices adopted by companies. 
The research can be justified in seeking help with managerial accounting, especially with the budgeting issue. Being one of the most important management tools used by organizations, budgeting needs improvement and contributions to meet the expectations and needs of its users. With the dynamism and competitiveness of today's business world, organizations need the support of efficient techniques to work in this context and ensure positive outcomes. Regarding to the model, the literature contributes with studies like this to bring us a concise understanding about the reality. For example, models about management control try to demonstrate how firms plan, motivate, evaluate and reward performance (Ferreira \& Otley, 2009; Malmi \& Brown, 2008; Simons, 1995). Moreover, the present model, inside of management control perspective, is important because it tries to summarize and indicate budgeting practices to be followed.

This paper first reviews relevant literature regarding budgeting practices in stages of planning, execution and control. In methodology, we present how we develop the model and the adhesion test. The results section shows the model and the questionnaire application. Finally, we discuss the results of the questionnaire and its application to the model.

\section{THEORETICAL BACKGROUND}

Horngren, Foster and Datar (1997) define budgeting as the quantification of management's plans for a certain period, in addition, may include financial and non-financial aspects and works as a project to be followed by the company. Thus, this review follows with the statement of the main budgeting practices identified in the literature and we divide them into the stages of planning, execution, and control.

\subsection{THE BUDGETING IN THE PLANNING STAGE}

The practices identified at this stage involve the phase in which organizations plan the budgeting. With the application of these practices, companies decide who are the people involved in each process and their responsibilities, therefore, to assist in maintaining the focus and assure the goal achievement.

The first practice identified is the use of a budget manual. According Cress and Pettijohn (1985), policies and procedures of the budgeting, personal responsibility and other activities related to the budgeting are generally described in a manual. Another practice is the formation of a budget committee. This committee aims to analyze the budgetary needs of the organization and recommend an approach to initiate and implement the budgeting (Joshi et al., 2003). The composition of the budget committee may cover managers of departments or divisions, accounting department, controller, senior management, functional areas, and others.

The type of the budgeting process used is also an observed practice. This practice can indicate whether the delegation of tasks occurs and, mainly, indicate whether the organization is centralizing information in senior management. Several studies have sought to identify how the budgeting process occurs, either top-down (predominance of senior management in decision making), bottom-up (greater involvement of lower levels in preparation) or a combination of this process. 
The time spent in budgeting preparation is also a checked item. According to Uyar and Bilgin (2011), several factors may influence the time taken, such as the organization complexity and its size. Surveys show that time spent may vary from weeks to months (Libby \& Lindsay, 2010; Schmidgall \& Ninemeier, 1986). The time period that the budgeting covers represents the period that the budgeting comprises. Uyar and Bilgin (2011) claim that there is a general acceptance that companies prepare budgets for one year, which is also confirmed by other studies (Ahmad \& Salleh, 2009; Almeida et al., 2009; Jones, 1998; Jones, 2008a).

Specific purposes served by budgeting consist of the reasons that motivate companies in its application, many of them are presented in different studies. Among these, we list the use for supporting strategy formulation and implementation (Almeida et al., 2009; Simons, 1990), control and performance evaluation (Jones, 1998; Libby \& Lindsay, 2010), facilitating the communication of goals and coordinate activities (Ahmad \& Salleh, 2009), support short and long term planning (Jones, 2008a), increase of profitability and variance analysis (Joshi et al., 2003), and the control of costs and expenses (Pavlatos \& Paggios, 2009).

Information used for budget planning includes verification of the base used by companies in the budgeting preparation. The use of consistent information reflects in a more accurate budgeting process. Information such as previous' year actual and budgeted results, national and local economic indicators, industry statistics and market analysis may be used (Jones, 1998).

The practice of conducting reviews allows budgeting changes due to modifications in the economic environment (Uyar \& Bilgin, 2011). The practice of identifying guidelines on revenue increase is presented in some studies, as Castro et al. (2012). The results indicate that the main technique used is simply a percentage increase over the previous year. Techniques such as improving the competitive set, expected inflation and statistical method are less used.

Besides budgeting components common to every type of business, such as financial information about operations, there is the approach of items that are part of the budgeting package. Steed and $\mathrm{Gu}$ (2009) show that the surveyed companies take into account mainly the capital expenditure (88\%), competitor assessment (83\%), marketing plan (81\%) and employees full-time and equivalents (71\%).

These studies also aim to know what types of budgeting are used. For example, the choice of activity based budgeting may indicate that the company already uses the activity based costing. Generally, studies observe whether the companies choose to use the traditional budgeting, zero base budgeting, flexible budgeting, continuous budgeting, activity based budgeting or beyond budgeting.

Regarding to the software used in the budgeting process management, Uyar and Bilgin (2011) mention that this is an important management issue, because the technology used directly influences the time taken during the whole process. Finally, regarding to the planning stage, we describe the practices related to the preparation of strategic planning and its time horizon. About strategic planning, one of the major research issues is the lack of synchrony between budgeting and strategic planning (Libby \& Lindsay, 2010).

\subsection{THE BUDGETING IN THE EXECUTION STAGE}

In the stage of implementation, researchers on budgeting practices often ask respondents to assess items of execution in the budgetary process. Joshi et al. (2003) inquired about the perception that the budgeting is a secret of top management. As the research sample was composed of listed and unlisted companies on the stock exchange, they realize a higher tendency for unlisted respondents to consider the budgeting a secret. Other items inquired also refer to whether the budgeting provides effective 
leadership, if there is the availability of an information flow, if the coordination between departments is achieved, and the way that firms prepare their goals.

In addition, studies observe motivational aspects at this stage. The main items involve employees' participation in the process, responsibilities and goals, and possible gamesmanship (Castro et al., 2012; Huang \& Chen, 2010). Uyar and Bilgin (2011) found in their research that the most important items are the clear definition of manager's responsibility and authority, the participation of managers so that they can consider the budgeting achievable (Locke \& Latham, 1990), and when the budgeting is used as a performance measure for managers.

Goal setting is an important part of the budgeting, where items such as participation in the process and difficulty in achieving the goals have been the subject of behavioral research in accounting (Otley, 1999). The results found by Merchant and Manzoni (1989) indicate lower difficulty in achieving goals in comparison with the literature, however, managers show advantages such as improved corporate communication, resource planning, control and motivation.

In addition to the strategic level, the participation of other levels in the budgeting is generally considered a healthy management policy. Participation alone does not necessarily provide an improvement in performance, it gives managers a greater sense of responsibility, increases organizational commitment, the probability of goals acceptance and reduces information asymmetry (Cress \& Pettijohn, 1985; Fisher, Maines, Peffer \& Sprinkle, 2002; Marginson \& Ogden, 2005; Parker \& Kyj, 2006; Subramaniam, Mcmanus \& Mia, 2002; Winata \& Mia, 2005; Zonatto \& Lavarda, 2013).

\subsection{THE BUDGETING IN THE CONTROL STAGE}

With reference to the control stage, the first practice identified concerns the criteria to evaluate the results and differences between budgeted and actual results. For this purpose, companies can choose benchmarking, and decide if they use landmarks or not. Castro et al. (2012) found that $93 \%$ of companies use landmarks and $7 \%$ do not use. Furthermore, regarding the ways for evaluating results, $57 \%$ of companies use percent variation, $43 \%$ of companies use monetary variation, and none of the firms use the repetition of an adverse variable.

The use of key performance measures to evaluate the budgeting is also an important budgeting practice. Uyar and Bilgin (2011) found that most companies make a comparison with previous results (72\%), comparisons between budgeted and actual results (53\%), comparisons between competitors $(16 \%)$, industry statistics (16\%) and the use of indicators and targets of assessment tools, such as the Balanced Scorecard or other (13\%).

As for its role in monitoring, Castro et al. (2012) point out in their research that $64 \%$ of companies claim to use budgeting as a key performance indicator and $36 \%$ as one of the few key indicators. Another practice identified concerns the possibility of providing budgeting reports at a specified frequency.

Another budgeting practice, the variance analysis, looks at who is responsible, what is the frequency and main purposes. Among the main purposes, studies list control of costs and expenses, potential problem identification in time to avoid it and feedback to the budgeting for the next period (Joshi et al., 2003). Cress and Pettijohn (1985) point out that the variance analysis is a departments' head's responsibility, followed by the budget committee and senior management.

The last practice verified in the process of control refers to steps applied in budgeting control. Castro et al. (2012) identified that comparative analysis is performed by $79 \%$ of firms, identifying deviations by 
$57 \%$, the analysis of the causes of deviations by $79 \%$ and the adequacy of measures by $64 \%$. Completing all of the steps it is important because the budgeting of the current year should provide feedback to the following year.

Table 1 summarizes the practices related to budgeting planning, since Budget Manual item to Strategic Planning item. Execution practices include items related to the Implementation of the Budgeting Process and Motivational Aspects. Finally, the control stage comprises items from Criteria for Assessing the Performance to Budgeting Control Steps.

Table 1: Practices related to the stages of planning, execution and control

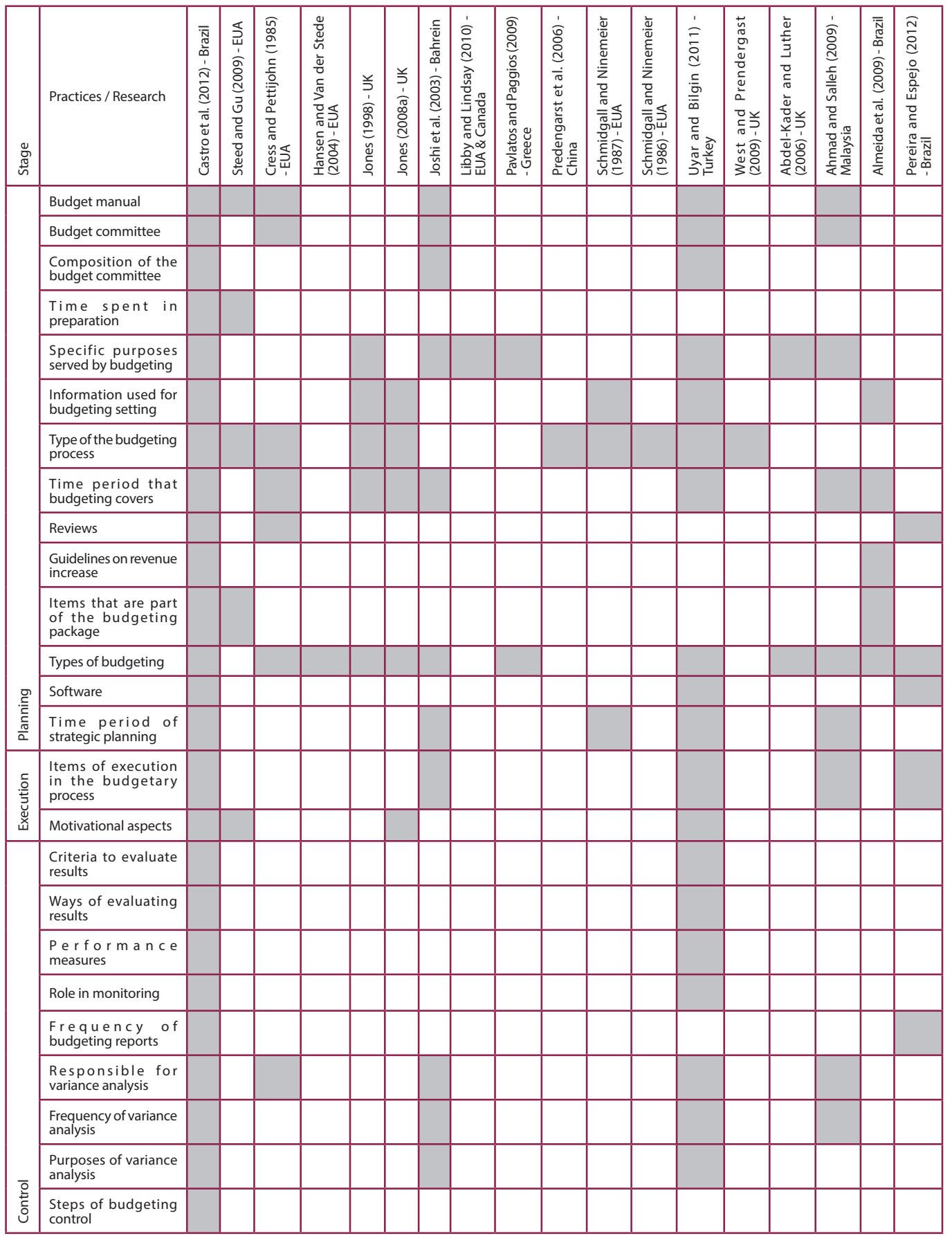




\section{METHODOLOGY}

In this chapter, we discuss aspects about the theoretical framework used for the model construction and for the budgeting practices addressed in the research. Furthermore, we present the way in which the adhesion test for the model was conducted.

\subsection{METHOD TO ELABORATE THE THEORETICAL FRAMEWORK}

As an intervention tool to collect bibliographic references, we adapted and used the ProKnow-C (Knowledge Development Process - Constructivist) (Bortoluzzi et al., 2011). We justify the use of a structured process of collection of the theoretical framework due to the diversity of sources of information for scientific work, such as scientific journals and databases.

\subsection{METHOD TO CONSTRUCT THE PROPOSED MODEL}

To construct the model we used the method of Multicriteria Decision Aiding (MCDA). These methods are derived from the French and American schools, and the constructivist method, MCDA-C, it is an offshoot of traditional MCDA and originated from Soft Operational Research used in decision making (Ensslin, Giffhorn, Ensslin, Petri \& Vianna, 2010). This study uses the MCDA-C approach, which aims to structure the decisional context in developing models to aid decision makers to substantiate their decisions based on what they believe to be most appropriate (Roy, 1993).

The MCDA-C is divided into three phases. Initially, the phase of contextualization is composed of three stages. In the stage of Soft Approach for Structuring, also called Contextualization, the description of the environment with the representation of the major concerns for the decision maker is taken. In the stage Viewpoints Tree construction it is performed the identification of Primary Elements of Assessment (EPA), its transformation into concepts, grouping them by affinity in areas of concern, which ultimately culminates in the construction of the tree. And in the stage of Construction of Descriptors is made the construction of cognitive maps, transforming the Tree Value in Hierarchical Structure Value, with the incorporation of Elementary Viewpoints from the Concepts to Clusters and Sub-Clusters grouping. Finally, the descriptors are constructed to best represent what decision makers deem as important (Ensslin et al., 2010).

In this first phase of MCDA-C model, the Contextualization, it was considered the knowledge of experts obtained from the literature review for building the Value in Hierarchical Structure Value and the definition of descriptors. In this way, as shown in Table 1, the budgeting practices were identified in the literature.

The Evaluation phase is divided into four stages and expands the understanding of the decision maker with the construction of scales and allocation of charges that represent their preferences. The stage of the Local Preference Scale Construction comprises the transformation of ordinal scales of descriptors to cardinal (interval scale) through its Value Function. The Determination of the Rates of compensation allows the integration of cardinal scales and definition of Global Value Performance. The Identification of Performance Profile Actions happens by measuring the current situation. And in the Results Analysis stage, aspects are highlighted with compromising, competitive and excellent performance (Ensslin, Dutra \& Ensslin, 2000). 
The last phase, Recommendations, aims to build knowledge through improvement actions to be performed and their effects. Additionally, a sensitivity analysis, in order to test the robustness of the model (Ensslin et al., 2010), is performed.

\subsection{ADHESION TEST}

We also performed an adhesion test to examine our model. This test was conducted through a questionnaire composed of budgeting practices identified by Castro et al. (2012). The questionnaire was adapted in response to the type of companies. While Castro et al. (2012) addressed the use of budgeting practices in hotels, this study covers other types of companies. From the questionnaire, we asked respondents about the use of planning, execution and control practices involving items previously presented in the literature review.

\subsection{SAMPLE}

The survey sample is characterized as intentional, which can be justified by just being used for adhesion test of the model. For this test, companies in the Industrial Goods Sector of BM\&FBovespa (Brazil's Stock Exchange) were contacted. After contact by email and telephone, were achieved 14 responses among 36 companies listed in this sector. The questionnaires were collected using a questionnaire available in Google Docs from September 2012 to April 2013. The questionnaire does not have the intention to conduct statistical inferences.

\subsection{BUDGETING PRACTICES}

The items shown in Table 1 we refer to this study as Critical Budgeting Practices, and in each of these items still exist subdivisions, which are called Elementary Budgeting Practices. For example, Types of Budgeting, relating to the planning stage, is a Critical Budgeting Practice. The subdivisions presented, which are Zero Base, Flexible, Continuous, Activities and Beyond Budgeting are Elementary Budgeting Practices. The Critical Practices related to the adoption of budget manual and the committee do not have subdivisions, therefore, they do not have Elementary Practices. All Critical and Elementary Budgeting Practices related to the planning stage are presented in Table 2 .

Table 2: Construct related to budgeting planning practices

\begin{tabular}{|c|c|c|}
\hline Critical budgeting practices & Elementary budgeting practices & Measures \\
\hline Budgeting manual & It has budgeting manual & Yes / No \\
\hline Budgeting committee & It has budgeting committee & Yes / No \\
\hline \multirow{8}{*}{ Composition of the budgeting committee } & Personnel Manager & \multirow{8}{*}{ Multiple choice } \\
\hline & Marketing Manager & \\
\hline & Accountant Manager / Controller & \\
\hline & Budgeting Director / Manager & \\
\hline & Finance Manager / Treasurer & \\
\hline & Owner(s) & \\
\hline & General Manager / Director & \\
\hline & Other & \\
\hline
\end{tabular}




\begin{tabular}{|c|c|c|}
\hline \multirow{4}{*}{ Time of budgeting preparation } & Less than 40 hours & \multirow{4}{*}{ Multiple choice } \\
\hline & From 41 to 80 hours & \\
\hline & From 81 to 120 hours & \\
\hline & More than 120 hours & \\
\hline \multirow{15}{*}{ Specific purposes served by budgeting } & Forecasts of future & \multirow{15}{*}{$\begin{array}{c}\text { Scale } 1 \text { to } 5 \\
1 \text { - strongly agree } \\
5 \text { - strongly disagree }\end{array}$} \\
\hline & Maximize results & \\
\hline & Introducing new products and services & \\
\hline & Planning, monitoring and assessing the result & \\
\hline & Creating incentives and rewards & \\
\hline & Price Decisions & \\
\hline & Assisting in long term planning & \\
\hline & Coordinating operations & \\
\hline & Assisting in the planning of short term & \\
\hline & Evaluating the performance & \\
\hline & Motivating Managers & \\
\hline & Motivating employees & \\
\hline & Reporting plans & \\
\hline & Control & \\
\hline & Planning profitability & \\
\hline \multirow{7}{*}{ Information used in setting budgeting } & Results from previous years & \multirow{7}{*}{$\begin{array}{l}\text { Scale } 1 \text { to } 5 \\
1-\text { never } \\
5 \text { - always }\end{array}$} \\
\hline & Industry statistics / indicators & \\
\hline & Market Analysis & \\
\hline & National economic indicators & \\
\hline & Figures from previous year's budget & \\
\hline & Local and regional economic indicators & \\
\hline & Other & \\
\hline \multirow{4}{*}{ Type of the budgeting process } & Top-down & \multirow{4}{*}{ Multiple choice } \\
\hline & Bottom-up & \\
\hline & Combination & \\
\hline & Other & \\
\hline \multirow{5}{*}{ Time period budgeting covers } & 1 month & \multirow{5}{*}{ Multiple choice } \\
\hline & 3 months & \\
\hline & 6 months & \\
\hline & 1 year & \\
\hline & Other & \\
\hline \multirow{4}{*}{ Reviews } & Monthly & \multirow{4}{*}{ Multiple choice } \\
\hline & Quarterly & \\
\hline & Semiannually & \\
\hline & Other & \\
\hline \multirow{5}{*}{ Guidelines on revenue increase } & Percentage increase over the previous year & \multirow{5}{*}{ Multiple choice } \\
\hline & Based on the improvement of the competitive set & \\
\hline & Based on expected inflation & \\
\hline & Statistical method (Regression etc.) & \\
\hline & Other & \\
\hline \multirow{7}{*}{$\begin{array}{l}\text { Items that are part of the budgeting } \\
\text { package }\end{array}$} & Capital expenditure & \multirow{7}{*}{ Multiple choice } \\
\hline & Evaluation of competition & \\
\hline & Marketing plan & \\
\hline & Full-time employees and equivalents & \\
\hline & Managements wages & \\
\hline & Salary Survey & \\
\hline & Other & \\
\hline
\end{tabular}




\begin{tabular}{|c|c|c|}
\hline \multirow{6}{*}{ Types of budgeting } & Traditional & \multirow{6}{*}{ Multiple choice } \\
\hline & Continuous & \\
\hline & Zero Base & \\
\hline & Flexible & \\
\hline & Activities & \\
\hline & Beyond budgeting & \\
\hline \multirow{4}{*}{ Software } & Spreadsheets (Excel) & \multirow{4}{*}{ Multiple choice } \\
\hline & Specific programs & \\
\hline & Excel and other programs & \\
\hline & Other & \\
\hline \multirow{5}{*}{ Time period of strategic planning } & 1 year & \multirow{5}{*}{ Multiple choice } \\
\hline & 3 years & \\
\hline & 5 years & \\
\hline & Over 5 years & \\
\hline & Other & \\
\hline
\end{tabular}

Source: Adapted from Castro et al. (2012).

As shown in Table 2, Table 3 and 4 also present measures used in the questionnaire for each practice. These measures are important because they will help to indicate the level of sophistication from adhesion test. In Castro et al. (2012), practices related to the information used for setting the budgeting and specific purposes served by budgeting were on execution stage. In this study the execution stage comprises items related to execution and motivational aspects. Elementary Budgeting Practices for each are presented in Table 3.

Table 3: Construct related to budgeting execution practices

\begin{tabular}{|c|c|c|}
\hline Critical budgeting practices & Elementary budgeting practices & Measures \\
\hline \multirow{7}{*}{$\begin{array}{l}\text { Items of execution in the budgetary } \\
\text { process }\end{array}$} & Secret of top management & \multirow{7}{*}{$\begin{array}{c}\text { Scale } 1 \text { to } 5 \\
1 \text { - strongly agree } \\
5 \text { - strongly disagree }\end{array}$} \\
\hline & Effective leadership is provided in the budgeting process & \\
\hline & Flow of information is available to the budgeting & \\
\hline & Coordination between departments is easily achieved & \\
\hline & $\begin{array}{l}\text { Goals are determined first by the department and then } \\
\text { submitted to top management }\end{array}$ & \\
\hline & $\begin{array}{l}\text { Goals are determined by top management and then opinions } \\
\text { are collected in the departments }\end{array}$ & \\
\hline & $\begin{array}{l}\text { Goals are the result of a structured process and aligned with the } \\
\text { Strategic Planning }\end{array}$ & \\
\hline \multirow{6}{*}{ Motivational aspects } & $\begin{array}{l}\text { The authority and responsibility of the individual manager } \\
\text { should be clear for effective budget }\end{array}$ & \multirow{6}{*}{$\begin{array}{c}\text { Scale } 1 \text { to } 5 \\
1 \text { - strongly agree } \\
5 \text { - strongly disagree }\end{array}$} \\
\hline & $\begin{array}{l}\text { Participation is essential for managers to accept their budgets } \\
\text { and consider it achievable }\end{array}$ & \\
\hline & The "gamesmanship" in the budgeting is harmful & \\
\hline & Bonuses are linked to the manager scope of budget goals & \\
\hline & Having an achievable, but difficult budget, motivates managers & \\
\hline & $\begin{array}{l}\text { Participation is important when the budget is a performance } \\
\text { measure for managers }\end{array}$ & \\
\hline
\end{tabular}

Source: Adapted from Castro et al. (2012).

The practices presented in Table 4 represent the features identified in the control step. Such practices include parameters used to control the results, analyze variations and performance evaluation.

Table 4: Construct related to budgeting control practices

\begin{tabular}{|l|r|c|}
\hline Critical budgeting practices & Elementary budgeting practices & Multiple choice Measures \\
\hline \multirow{3}{*}{ Criteria to evaluate results } & Benchmarking & \multirow{2}{*}{ Multiple choice } \\
\cline { 2 - 2 } & Not using landmarks & \\
\cline { 2 - 3 } & Use landmarks & \\
\hline
\end{tabular}




\begin{tabular}{|c|c|c|}
\hline \multirow{3}{*}{ Ways of evaluating results } & Change in Percent & \multirow{3}{*}{ Multiple choice } \\
\hline & Monetary variation & \\
\hline & Repetition of an adverse variable & \\
\hline \multirow{6}{*}{ Performance measures } & Comparison with results from previous years & \multirow{6}{*}{ Multiple choice } \\
\hline & Comparison of budgeted $\mathrm{X}$ performed amounts & \\
\hline & Indicators and targets of Assessment Tools (BSC or other) & \\
\hline & Comparisons with competitors & \\
\hline & Industry statistics & \\
\hline & Other & \\
\hline \multirow{3}{*}{ Role in monitoring } & Key performance indicator & \multirow{3}{*}{ Multiple choice } \\
\hline & One of the few key indicators used & \\
\hline & Little used as a performance measure & \\
\hline \multirow{4}{*}{ Frequency of budgeting reports } & Monthly & \multirow{4}{*}{ Multiple choice } \\
\hline & Semiannually & \\
\hline & Annually & \\
\hline & Other & \\
\hline \multirow{6}{*}{ Responsible for variance analysis } & Heads of departments & \multirow{6}{*}{ Multiple choice } \\
\hline & Top management & \\
\hline & Budget Committee & \\
\hline & General Manager & \\
\hline & Controller & \\
\hline & Other & \\
\hline \multirow{5}{*}{ Frequency of variance analysis } & Monthly & \multirow{5}{*}{ Multiple choice } \\
\hline & Quarterly & \\
\hline & Semiannually & \\
\hline & Annually & \\
\hline & Other & \\
\hline \multirow{6}{*}{ Purposes of variance analysis } & Evaluating the performance of the manager & \multirow{6}{*}{ Multiple choice } \\
\hline & Evaluating the provision manager & \\
\hline & Control costs / expenses & \\
\hline & Identifying a potential problem in time to avoid it & \\
\hline & Feedback for the next budget period & \\
\hline & Other & \\
\hline \multirow{4}{*}{ Steps applied in budgeting control } & Comparative Analysis & \multirow{4}{*}{ Multiple choice } \\
\hline & Identification of deviations & \\
\hline & Analysis of the causes of deviations & \\
\hline & Adequacy measures & \\
\hline
\end{tabular}

Source: Adapted from Castro et al. (2012).

The choice of Castro et al. (2012) is justified because their study might be understood as a pre-test to the choice of budgeting practices presented in Table 1. Although previous studies presented in Table 1 were the basis to increase understanding of individual budgeting practices, they do not present the different practices in a systemic and holistic view. Thus, Castro et al. (2012) group the practices addressed in the literature enabling add the different practices into a single model for understanding the use of budgeting in different contexts.

However, the absence of measures to assess the level of sophistication of practices is perceived as a limitation on Castro et al. (2012). Therefore, the construction of the model proposed in this research allows improvement to the analysis of Castro's and other studies.

It is noteworthy that some limitations derive from this choice. First, the identification of appraisal criteria of budget practices is performed based on the interpretation of literature, and it is not from perception or empirical knowledge of managers. In addition, the measurement of each budgeting 
practice is done individually by observing the percentage of analyzed companies that adopt this practice, representing an estimate (average) of adoption. Finally, there is no integration of scales to express overall assessment of value and the management is done through the description of each critical or elementary budgeting practice.

\section{MODEL CONSTRUCTION}

As described previously, to structure the model and to assess the level of sophistication, we started with the budgeting practices presented by Castro et al. (2012). With the budgeting practices defined, we proceeded with the search of other studies that empirically addressed such practices, then we collected their outcomes.

After the identification of the studies, we performed the analysis and transcription of practices to the model. In this way, to legitimize the model, we applied a questionnaire with the budgeting practices to test the adhesion of the model in a sample of companies. With the questionnaire and its results, we reviewed and adjusted the practices to the model and performed the required subdivisions.

After the questionnaire, the practices were expanded to the extent that the research could be measured, starting with the critical factors (critical practices) to the elementary practices of budgeting. At the end of this process it was observed whether the model is exhaustive regarding to the literature and if there was how to measure the practices, if so, the model is finalized.

\subsection{METHOD OF EVALUATION OF THE MODEL}

To determine the levels of sophistication of the model, we transformed the ordinal scales into cardinal scales through of value function. Ordinal scales are the descriptors, and according to Ensslin, Montibeler Neto and Noronha (2001), these descriptors measure the concerns of decision makers and may also be defined as a set of impact levels. Each level of impact may be understood as representing the performance of each potential action.

In this study, the type of descriptors we used is quantitative. The use of this descriptor is due to the fact that ordinal scales are originated from previous research results, which are both in percentage terms and in Likert scale, from 1 to 5 (Likert, 1932). One example of descriptor could be the percentage of budgeting manual adoption, and then this percentage will be transformed to a cardinal scale.

After ordinal scales defined by descriptors, we performed their quantification by the value function. Value Function is a tool that can assist decision makers to express their preference numerically with the ordering of intensity of preferences between pairs of levels of impact or potential actions (Ensslin, Montibeler Neto \& Noronha, 2001). A value function must be built by the decision maker for her/his point of view.

There are several methods in the literature about function value. Among these, is the Direct Method of Score, the Bisection Method and the Method of Judgment Semantic (Ensslin, Montibeler Neto \& Noronha, 2001). For the present study, we used the method of the Direct Score.

The method of the Direct Score requires pre-built descriptors, being qualitative as well as quantitative, formed by a set of impact levels, ordered from the worst to the best. In order to anchor the scale, we assigned to these levels a zero in the lower and 100 to the upper level. It is noteworthy that for this method there is no fixed zero, it is a way to anchor the judgments of the decision maker, which can be called worse acceptable or neutral (Ensslin et al., 2010). 


\subsection{PRESENTATION OF THE MODEL}

The map of the model is divided as described in the literature, between the stages of planning, execution, and control. The purpose is to show the position of the practices found in previous studies on the scale and assess its level of sophistication. It is shown in Figure 1 a fragment of the map with ordinal scales (percentage) on the left and cardinal scales on the right side of the arrows.

Figure 1: Model of budgeting practices evaluation

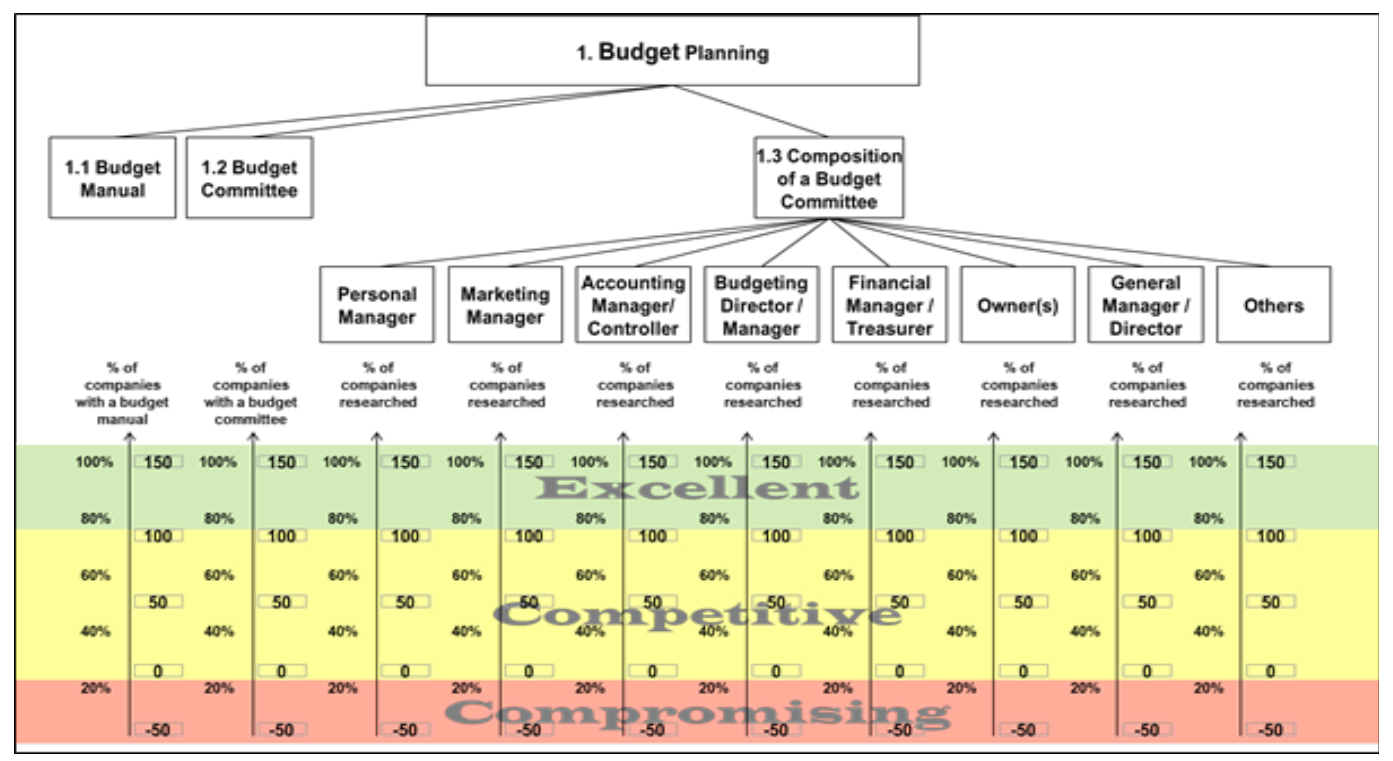

As shown in Figure 1, we present a portion of the model concerning the planning stage where are percentages for evaluation. The percentages (left scales) constitute the ordinal scales, or descriptors, which indicate the results obtained in previous research. From the direct scoring method, these descriptors were transformed into linear cardinal scales anchored between 0 and 100, lower and upper level, respectively.

To avoid possible misinterpretations of value judgment, $25 \%$ was established as a percentage of the lower level and $75 \%$ of the upper level. Thus, studies that offer budgeting practices with results between $25.1 \%$ and $75 \%$ fall in the Competitive level. And practices with less than $25 \%$ are classified as compromising level and those practices with more than $75 \%$ are classified as excellent performance level.

Furthermore, budgeting practices investigated by Likert scale have their cardinal scales anchored between 0 and 100 for means presented between 2 and 4 . That is, the results of budgeting practices with means below 2 result in a number lower than 0 to cardinal scale level (compromising), the results above 4 in a number greater than 100 for the cardinal scale (excellent level) and the results between 2 and 4 generate a cardinal scale that remains between 0 and 100 (competitive level).

Finally, in each stage, critical or elementary practices have a weight in the model. We defined the weights for stages of planning (40\%), execution (20\%) and control (40\%) according to the quantity of elementary practices in each of them. After that, the sum of percentages for all critical practices is equal to $100 \%$ in each stage; in the planning stage, for example, each critical practice has a charge about $7,1 \%$, in the execution stage, as we just have two critical practices, both have $50 \%$ of charge, and critical 
practices in the control have about $11 \%$. Table 5 presents an example of the levels and charges for the critical practice of software and its elementary practices.

Table 5: Method of calculus for the model

\begin{tabular}{|c|c|c|c|c|c|c|c|c|c|c|}
\hline \multicolumn{2}{|c|}{ Budgeting Practices (a) } & $\begin{array}{c}\text { Charge } \\
\text { (b) }\end{array}$ & $\begin{array}{l}\text { Upper } \\
\text { level (c) }\end{array}$ & Lower level (d) & Good (e) & $\begin{array}{c}\text { Neutral } \\
\text { (f) }\end{array}$ & $\begin{array}{l}\text { Cardinal } \\
\text { Scale (g) }\end{array}$ & $\begin{array}{l}\text { S u r v e y } \\
\text { Responses } \\
\text { (h) }\end{array}$ & $\begin{array}{l}\text { Cardinal } \\
\text { Scale (i) }\end{array}$ & $\begin{array}{l}\text { Castro et } \\
\text { al. (j) }\end{array}$ \\
\hline \multicolumn{2}{|c|}{ Software (Critical practice) } & $7,1 \%$ & & & & & & & & \\
\hline \multirow{4}{*}{ 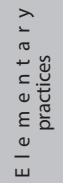 } & Spreadsheets $\left(\right.$ Exce| $\left.\left.\right|^{\oplus}\right)$ & $25,0 \%$ & $75 \%$ & $25 \%$ & 100 & 0 & -36 & $7,1 \%$ & 22 & $36 \%$ \\
\hline & Specific programs & $25,0 \%$ & $75 \%$ & $25 \%$ & 100 & 0 & -36 & $7,1 \%$ & -36 & $7 \%$ \\
\hline & $\begin{array}{l}\text { Excel and other } \\
\text { programs }\end{array}$ & $25,0 \%$ & $75 \%$ & $25 \%$ & 100 & 0 & 122 & $85,8 \%$ & 36 & $43 \%$ \\
\hline & Other & $25,0 \%$ & $75 \%$ & $25 \%$ & 100 & 0 & -50 & $0,0 \%$ & -22 & $14 \%$ \\
\hline
\end{tabular}

In the columns ' $j$ ' and ' $h$ ' we present the results of Castro et al. (2012) and the adhesion test (ordinal scale), respectively, and in columns ' $i$ ' and ' $g$ ' the results of the cardinal scale, which generate the score of Figure 1. The results of cardinal scales of Table 5 take into account the anchorage ( 0 and 100) and the lower $(25 \%)$ and upper $(75 \%)$ levels. The cardinal scale -36 of Excel use is resulted from the following equation: the ratio of the result from lower level $(25 \%)$ minus the research answers $(7.1 \%)$ multiplied by good (100) and lower level (25\%) minus upper level (75\%).

In practice, the level of sophistication assessment of the use of budgeting practices can contribute to the effectiveness of the use of budgeting by organizations, in a way that they meet their expectations regarding the achievement of goals, and, consequently their results. As sustained by Ensslin, Montibeler Neto and Noronha (2001), a company that has your budget in the competitive level has a tool that helps to remain on the market, while a company that has the budgeting at an excellent level has an instrument that contributes to the achievement of results and to be differentiated if compared to competitors.

\subsection{ANALYSIS OF ADHESION TEST TO PROPOSED MODEL}

The model we propose may be used in evaluating research results of the use of budgeting practices. Objectively, it provides a picture of how companies use budgeting practices. Thus, the adhesion test is performed from a questionnaire adapted from Castro et al. (2012) with 14 companies in the Industrial Goods sector of BM\&FBovespa. Simultaneously, compares with Castro et al. (2012)'s results.

Jones (2008b) also carried out a study involving budgeting practices. From a verification by Chi-Square test, practices with significant results were considered as normative and non-normative, and with no significant results, as probably normative and probably non-normative.

After defined as normative or not, the model pointed to several aspects of the budget, such as the stages of the process, reasons for preparation and period time that covers. Furthermore, the use of flexible and zero base budgeting, goals, control techniques and evaluation of performance, participation and use of the budgeting by the managers were analyzed.

Among the results, the model suggests that hotels need to rethink some practices. As an example, it mentions the levels of participation by management in the budgeting process, particularly managers of departments, and also the lack of routine revisions of budgetary procedures. Additionally, she identified the need for financial training of non-financial managers as a key issue for companies.

Among the aspects considered normative, the model indicates the purposes of the budget for planning, control and performance evaluation; the budgeting period for one year; the use of flexible budgeting; the use of the budgeting as a goal; participation in budgeting and a standard process of construction; and the use of budgeting as a management tool. 
In Table 6, we show the results of the critical practices of budget. Initially, it can be seen that the model gives a lower result, compromising, to critical practices that have budgeting practices of the questionnaire mutually exclusive alternatives. For example, practices related to budget periods, such as the period required to establish the budgeting, frequency of reports, the period for which it is intended, the period of strategic planning, among others. Other critical practices that also have mutually exclusive options among its budgeting practices, such as the form of elaboration.

If we look closely, this might not be a limitation. For example, when a survey is conducted and differences among industries are considered, suppose that a firm does not follow what the others do, the practices in which that firm uses might not be sophisticated if we consider its industry. That is, if most firms in a determined industry consider 5 years for strategic planning and one firm considers 3 years in this same sector, the practice this firm adopts might not be considered sophisticated.

Table 6: Adhesion test to the model

\begin{tabular}{|c|c|c|c|c|c|c|c|c|c|c|}
\hline Critical Practices & $\begin{array}{l}\text { Charges } \\
\text { to each } \\
\text { stage }\end{array}$ & $\begin{array}{l}\text { Charges } \\
\text { to each } \\
\text { critical } \\
\text { practices }\end{array}$ & $\begin{array}{l}\text { Upper } \\
\text { Level }\end{array}$ & $\begin{array}{l}\text { Lower } \\
\text { Level }\end{array}$ & Good & Neutral & $\begin{array}{l}\text { Survey } \\
\text { responses } \\
\text { Adhesion } \\
\text { test }\end{array}$ & $\begin{array}{c}\text { Sophistication } \\
\text { Level }\end{array}$ & $\begin{array}{l}\text { Castro et } \\
\text { al. (2012) } \\
\text { Adhesion } \\
\text { test }\end{array}$ & $\begin{array}{c}\text { Sophistication } \\
\text { Level }\end{array}$ \\
\hline 1.1 Budget manual & & $7,1 \%$ & $75 \%$ & $25 \%$ & 100 & 0 & 136,0 & Excellent & $-50,0$ & Compromising \\
\hline 1.2 Budget committee & & $7,1 \%$ & $75 \%$ & $25 \%$ & 100 & 0 & 88,0 & Competitive & $-8,0$ & Compromising \\
\hline $\begin{array}{l}1.3 \text { Composition of the } \\
\text { budget committee }\end{array}$ & & $7,1 \%$ & $75 \%$ & $25 \%$ & 100 & 0 & 9,0 & Competitive & 5,3 & Competitive \\
\hline $\begin{array}{c}\text { 1.4 Time spent in } \\
\text { preparation }\end{array}$ & & $7,1 \%$ & $75 \%$ & $25 \%$ & 100 & 0 & 0,0 & Competitive & 0,0 & Competitive \\
\hline $\begin{array}{l}\text { 1.5 Specific purposes } \\
\text { served by budgeting }\end{array}$ & & $7,5 \%$ & $75 \%$ & $25 \%$ & 100 & 0 & 108,0 & Excellent & 118,7 & Excellent \\
\hline $\begin{array}{l}\text { 1.6 Information used in } \\
\text { setting budgeting }\end{array}$ & & $7,3 \%$ & $75 \%$ & $25 \%$ & 100 & 0 & 81,5 & Competitive & 93,3 & Competitive \\
\hline $\begin{array}{l}\text { 1.7 Type of the budgeting } \\
\text { process }\end{array}$ & & $7,1 \%$ & $75 \%$ & $25 \%$ & 100 & 0 & 0,0 & Competitive & 0,0 & Competitive \\
\hline $\begin{array}{l}\text { 1.8 Time period budgeting } \\
\text { covers }\end{array}$ & & $7,1 \%$ & $75 \%$ & $25 \%$ & 100 & 0 & $-10,0$ & Compromising & $-10,0$ & Compromising \\
\hline 1.9 Reviews & & $7,1 \%$ & $75 \%$ & $25 \%$ & 100 & 0 & 0,3 & Competitive & 0,0 & Competitive \\
\hline $\begin{array}{l}\text { 1.10 Guidelines on revenue } \\
\text { increase }\end{array}$ & & $7,1 \%$ & $75 \%$ & $25 \%$ & 100 & 0 & 13,0 & Competitive & $-28,0$ & Compromising \\
\hline $\begin{array}{l}1.11 \text { Items that are part of } \\
\text { the budgeting package }\end{array}$ & & $7,1 \%$ & $75 \%$ & $25 \%$ & 100 & 0 & 60,1 & Competitive & 35,8 & Competitive \\
\hline 1.12 Types of budgeting & & $7,1 \%$ & $75 \%$ & $25 \%$ & 100 & 0 & 4,6 & Competitive & $-16,6$ & Compromising \\
\hline 1.13 Software & & $7,1 \%$ & $75 \%$ & $25 \%$ & 100 & 0 & 0,0 & Competitive & 0,0 & Competitive \\
\hline $\begin{array}{l}\text { 1.14 Time period of } \\
\text { strategic planning }\end{array}$ & & $7,1 \%$ & $75 \%$ & $25 \%$ & 100 & 0 & $-1,6$ & Compromising & $-10,0$ & Compromising \\
\hline $\begin{array}{l}2.1 \text { Items of execution in } \\
\text { the budgetary process }\end{array}$ & & $50,0 \%$ & $75 \%$ & $25 \%$ & 100 & 0 & 100,4 & Excellent & 96,7 & Competitive \\
\hline 2.2 Motivational aspects & & $50,0 \%$ & $75 \%$ & $25 \%$ & 100 & 0 & 116,6 & Excellent & 95,3 & Competitive \\
\hline $\begin{array}{l}\text { 3.1 Criteria to evaluate } \\
\text { results }\end{array}$ & & $11,0 \%$ & $75 \%$ & $25 \%$ & 100 & 0 & 31,0 & Competitive & 16,6 & Competitive \\
\hline $\begin{array}{l}3.2 \text { Ways of evaluating } \\
\text { results }\end{array}$ & & $11,0 \%$ & $75 \%$ & $25 \%$ & 100 & 0 & 54,7 & Competitive & 16,7 & Competitive \\
\hline 3.3 Performance measures & & $11,0 \%$ & $75 \%$ & $25 \%$ & 100 & 0 & 31,1 & Competitive & 16,4 & Competitive \\
\hline 3.4 Role in monitoring & & $11,0 \%$ & $75 \%$ & $25 \%$ & 100 & 0 & 16,7 & Competitive & 16,7 & Competitive \\
\hline $\begin{array}{l}\text { 3.5 Frequency of } \\
\text { budgeting reports }\end{array}$ & & $11,0 \%$ & $75 \%$ & $25 \%$ & 100 & 0 & 0,0 & Competitive & 0,0 & Competitive \\
\hline $\begin{array}{l}\text { 3.6 Responsible for } \\
\text { variance analysis }\end{array}$ & & $11,0 \%$ & $75 \%$ & $25 \%$ & 100 & 0 & 38,3 & Competitive & 4,7 & Competitive \\
\hline $\begin{array}{l}\text { 3.7 Frequency of variance } \\
\text { analysis }\end{array}$ & & $11,0 \%$ & $75 \%$ & $25 \%$ & 100 & 0 & $-18,6$ & Compromising & $-10,4$ & Compromising \\
\hline $\begin{array}{c}\text { 3.8 Purposes of variance } \\
\text { analysis }\end{array}$ & & $12,0 \%$ & $75 \%$ & $25 \%$ & 100 & 0 & 30,9 & Competitive & 50,2 & Competitive \\
\hline $\begin{array}{l}\text { 3.9 Steps of budgeting } \\
\text { control }\end{array}$ & & $11,0 \%$ & $75 \%$ & $25 \%$ & 100 & 0 & 96,5 & Competitive & 89,5 & Competitive \\
\hline
\end{tabular}


Regarding to the calculus, the critical practice scores take into account the charges of each critical practice (100\% divided among each of them). For instance, the cardinal scale for the critical practice in Table 5, software, is the sum of the result of each elementary practice multiplied by elementary charges, $25 \%$ in this case.

It is observed that the initial two practices of the adhesion test (1.1 and 1.2) have their score points higher or close to 100 , thus the use of budget manual by companies surveyed is presented as excellent level. The formation of the budget committee constitutes a practice that approaches the level of excellence, however, because of the score achieved, it situates in a competitive level.

The main difference observed between samples investigated are the initial critical practices (items from 1.1 to 3.9), the adoption of the manual and a budget committee. According to Frezatti (2009), budgetary guidelines represent the translation of the strategic planning for its implementation during the budgeting, however, it appears that among the hotels surveyed by Castro et al. (2012) this is the practice less adopted, or in the compromising level. Cress and Pettijohn (1985), despite the year, has a utilization rate of 49.3\%, more recent studies as Joshi et al. (2003) and Ahmad and Salleh (2009) have a higher incidence of use of this practice.

According to Cress and Pettijohn (1985), the budgeting process is persuasive within organizations, and, for this reason, some companies set up a committee to facilitate the process completion and its improvement. In this practice, the discrepancy observed in the samples is lower if compared to the use of the manual, but it is also an aspect reported with a compromising level. Conversely, Uyar and Bilgin (2011) demonstrated a rate of $87.5 \%$ for the utilization of the budget committee.

With the exception of critical practices 1.1 and 1.2, the others follow a similar trend, in other words, if we look closely at Table 6 it is apparent that both samples, adhesion test and Castro et al. (2012), reached similar results. Each elementary practice of budgeting exerted influence on the result achieved, for example, it appears that the software used and Types of Budget (1.12 and 1.13) practices are between the Competitive and compromising levels due to use of only a few options, however, as a greater diversity of types of budget or software used, the greater the sophistication of the instrument.

Finally, the evaluation of the surveyed samples allows the identification of practices that are not in the level of excellence, that is, less sophisticated; with the identification of the sophistication level, firms can pursue improvement actions. There are several practices that are not presented in level of excellence, and for this reason, the adoption of such practices is configured in action for improvement.

The main advantage of the model is because it helps to summarize the decisions made by the decision makers. For example, this model could show us the principal practices used by organizations and, with the aid of Hierarchical Structure Value, evaluate the level of sophistication of each practice.

\section{CONCLUSION}

This study had as the aim to construct a model to assess the level of sophistication of budgeting practices used by companies. To accomplish this study, we used the budgeting practices indicated by Castro et al. (2012). We used Castro's study because it configures as a grouping of several budgeting practices presented previously in the literature. Moreover, we identified others previous studies that have addressed such practices. From such budgeting practices, we constructed the model with support of MCDA-C methodology and a questionnaire for the adhesion test. 
As a contribution to the literature on budgeting, if we look Table 1 we can see that most previous studies performed surveys on the use of practices. Meanwhile, this study provides a greater organization of the practices most addressed in the literature by fulfilling the segregation between the stages of planning, execution, and control. This development enabled the assessment of the budget for each of the practices, and then generating the result of stages and the identification of the overall performance.

The level of sophistication that the model allowed to observe is related to the adoption of the budgeting practices. Higher the rate of adoption of the practices observed in the research, higher the level of sophistication. A clear example is the adoption of the Budget Manual for almost all companies surveyed by the adhesion test, and as a consequence, this practice stands at an Excellence level. On the other hand, none of the companies surveyed by Castro et al. (2012) adopted the Manual Budget and the practice was in a compromising level. The improvement action indicated is the adoption of this practice, which contributes to the increased level of sophistication, both for the practice itself and for the instrument.

The verification of specific purposes served by budgeting preparation, practice in which companies use several elementary practices, therefore, configured as level of Excellence. However, the level of sophistication can also be increased due to the fact that the model allows the measurement of each of the practices and identify which stage of sophistication the company is located.

The main contribution of the model is the ability to review the practices of budgeting and to measure the level of sophistication that is utilized. With the use of cardinal scales, the research findings may appear at three levels: compromising, competitive, and excellent. With this review, the model allows the identification of deficient aspects that can be improved. The results of the adhesion test, as well as the verification of previous studies, have shown that this model enables the visualization and demonstrates clearly the aspects that contribute negatively or positively to the performance achieved.

Furthermore, the model allows researchers to plot comparisons between samples with a visual representation of your results. Comparisons can be made between samples with different industries, countries in which they are located, among others. The results can be compared from each practice to each stage of the budgeting, with the generation of the overall result of the sophistication level.

Umapathy (1987) states that successful companies use certain practices of budgeting, thus, we conclude that the model helps to use an instrument from another area of knowledge to measure the use of such practices and we perform an adhesion test for demonstration. We also emphasize that the literature indicates shortcomings in the budgeting, among them, that it is a lengthy process and inhibits innovation. Thereby, facilitating the identification of critical points, the model can contribute positively to the budgeting process in organizations.

With respect to the normative model proposed by Jones (2008b), our study does not suggest certain practices to be followed as normative, but rather, indicates the sophistication level of each practice and point where improvements should be made to improve its sophistication. Given the fact that the model is applicable to samples of research, it is important to take into consideration that each organization is different, then is necessary to seek to identify the influence of each one to the result.

As a result of indicating aspects to be improved, the model aims to increase the efficiency of the budgeting process of the organizations and make the budgeting near of reality, in other words, most likely to reach the results as they were budgeted. In this way, achieving goals and expected results.

Among the limitations of this study, some budgeting practices have exclusive responses, which led to decreased performance of some practices options assessed. Therefore, items listed as compromising, for example, could appear in the competitive or excellent level. Another aspect concerns the budgeting practices assessed, because in the reality of organizations other practices may be used. Furthermore, 
we notice that previous research and the adhesion test are performed from questionnaires about confidential company information that not always reflect the truth.

From the limitations, as the present study permits evaluation of the sophistication level of research, we suggest for future research to improve the model and its descriptors to allow the assessment of the level of sophistication of the budgeting directly in companies. Furthermore, the review of the literature in order to update the budgeting practices and exploitation of factors with potential influence on the use of a practice over another.

REFERENCES

Abdel-Kader M. \& Luther, R. (2006). Management accounting practices in the British food and drinks industry. British Food Journal, 108(5), 336-357.

Abratt, R., Beffon, M. \& Ford, J. (1994). Relationship between marketing planning and annual budgeting. Marketing Intelligence \& Planning, 12(1), 22-28.

Ahmad, M. F. \& Salleh, A. (2009). Budget Planning, Control and Evaluation: An Overview of Its Practices in Manufacturing. In: Reflecting on Accounting Research Issues, Penerbit UTM Press, Skudai, Johor, 83-102.

Almeida, L. B., Machado, E. A., Raifur, L. \& Nogueira, D. R. (2009). A Utilização do orçamento como ferramenta de apoio à formulação de estratégia, de controle e de interatividade: Um estudo exploratório nas cooperativas agropecuárias da Região Sul do Brasil. Revista Contabilidade Vista \& Revista, 20(3), 65-99.

Bortoluzzi, S. C., Ensslin, S. R. \& Ensslin, L. (2011). Avaliação de desempenho multicritério como apoio à gestão de empresas: Aplicação em uma empresa de serviços. Gestão \& Produção, 18(3), 633-650.

Bortoluzzi, S. C., Ensslin, S. R., Ensslin, L. \& Valmorbida, S. M. I. (2011). Avaliação de desempenho em redes de pequenas e médias empresas: Estado da arte para as delimitações postas pelo pesquisador. Revista Eletrônica de Estratégia e Negócios, 4(2), 202-222.

Castro, J. K., Souza, P., Santos, G. R. \& Lunkes, R. J. (2012). Prácticas presupuestarias aplicadas a las empresas hoteleras de Brasil: Un estudio en la ciudad de Florianópolis. Estudios y Perspectivas en Turismo, 21(4), 904-924.

Cress, W. P. \& Pettijohn, J. B. (1985). A survey of budget-related planning and control policies and procedures. Journal of Accounting Education, 3(2), 61-78.

Ensslin, L., Giffhorn, E., Ensslin, S. R., Petri, S. M. \& Vianna, W. B. (2010). Avaliação do desempenho de empresas terceirizadas com o uso da metodologia multicritério de apoio à decisão-construtivista. Pesquisa Operacional, 30(1), 125-152.

Ensslin, L., Montibeler Neto, G. \& Noronha, S. M. (2001). Apoio à decisão: Metodologia para estruturação de problemas e avaliação multicritério de alternativas. Florianópolis: Insular. 
Ferreira, A., \& Otley, D. (2009). The design and use of performance management systems: An extended framework for analysis. Management accounting research, 20(4), 263-282.

Fisher, J. G., Maines, L. A., Peffer, S. A. \& Sprinkle, G. B. (2002). Using budgets for performance evaluation: Effects of resource allocation and horizontal information asymmetry on budget proposals, budget slack, and performance. The Accounting Review, 77(4), 847-865.

Frezatti, F. (1999). Orçamento empresarial: Planejamento e controle gerencial. São Paulo: Atlas.

Hansen, S. C., Otley, D. T. \& Van Der Stede, W. A. (2003). Practice developments in budgeting: An overview and research perspective. Journal of Management Accounting Research, 15(1), 95-116.

Hansen, S. C. \& Van Der Stede, W. A. (2004). Multiple facets of budgeting: An exploratory analysis. Management Accounting Research, 15(4), 415-439.

Horngren, C. T., Foster, G. \& Datar, S. M. (1997). Contabilidade de custos. 9. ed. Rio de Janeiro: LTC.

Huang, C. L., \& Chen, M. L. (2010). Playing devious games, budget-emphasis in performance evaluation, and attitudes towards the budgetary process. Management Decision, 48(6), 940-951.

Jones, T. A. (1998). UK hotel operators use of budgetary procedures. International Journal of Contemporary Hospitality Management, 10(3), 96-100.

Jones, T. A. (2008a). Changes in hotel industry budgetary practice. International Journal of Contemporary Hospitality Management, 20(4), 428-444.

Jones, T. A. (2008b). Improving hotel budgetary practice: A positive theory model. International Journal of Hospitality Management, 27(4), 529-540.

Joshi, P. L., Al-Mudhaki, J. \& Bremser, W. G. (2003). Corporate budget planning, control and performance evaluation in Bahrain, Managerial Auditing Journal, 18(9), 737-750.

Libby, T. \& Lindsay, R. M. (2010). Beyond budgeting or budgeting reconsidered? A survey of North-American budgeting practice. Management Accounting Research, 21(1), 56-75.

Likert, R. (1932). A Technique for the measurement of attitudes. Archives of Psychology, 22(140), 5-55.

Locke, E. A., \& Latham, G. P. (1990). A theory of goal setting \& task performance. Prentice-Hall, Inc.

Malmi, T., \& Brown, D. A. (2008). Management control systems as a package-Opportunities, challenges and research directions. Management accounting research, 19(4), 287-300.

Marginson, D. \& Ogden, S. (2005). Coping with ambiguity through the budget: The positive effects of budgetary targets on managers' budgeting behaviours. Accounting, Organizations and Society, 30(5), 435-456. 
Merchant, K. A. \& Manzoni, J. F. (1989). The achievability of budget targets in profit centers: A field study. Accounting Review, 64(3), 539-558.

Otley, D. (1999). Performance management: A framework for management control systems research. Management Accounting Research, 10(4), 363-382.

Parker, R. J. \& Kyj, L. (2006). Vertical information sharing in the budgeting process. Accounting, Organizations and Society, 31(1), 27-45.

Pavlatos, O. \& Paggios, I. (2009). Management accounting practices in the Greek hospitality industry. Managerial Auditing Journal, 24(1), 81-98.

Pereira, F. A. \& Espejo, M. M. S. B. (2012). Planejamento e controle orçamentário em empresas concessionárias de rodovias: Uma pesquisa empírica. Revista Contemporânea de Contabilidade, 9(17), 121-142.

Predengarst, G., West, D. \& Shi, Y. Z. (2006). Advertising budgeting methods and process in China. Journal of Advertising, 35(3), 165-176.

Rosa, F. S., Ensslin, S. R., Ensslin, L. \& Lunkes, R. J. (2012). Environmental disclosure management: A constructivist case. Management Decision, 50(6), 1117-1136.

Roy, B. (1993). Decision science or decision-aid science?. European journal of operational research, 66(2), 184-203.

Schmidgall, R. S. \& Ninemeier, J. D. (1986). Food-service budgeting: How the chains do it. Cornell Hotel and Restaurant Administration Quarterly, 26(4), 51-56.

Schmidgall, R. S., \& Ninemeier, J. D. (1987). Budgeting in hotel chains: Coordination and control. Cornell Hotel and Restaurant Administration Quarterly, 28(1), 78-84.

Simons, R. (1990). The role of management control systems in creating competitive advantage: New perspectives. Accounting, Organizations and Society, 15(112), 127-143.

Simons, R. (1995). Levers of Control. Harvard Business School Press, Boston.

Steed, E. \& Gu, Z. (2009). Hotel management company forecasting and budgeting practices: a survey-based analysis. International Journal of Contemporary Hospitality Management, 21(6), 676-697.

Subramaniam, N., Mcmanus, L. \& Mia, L. (2002). Enhancing hotel managers' organisational commitment: an investigation of the impact of structure, need for achievement and participative budgeting. International Journal of Hospitality Management, 21(4), 303-320.

Tasca, J. E., Ensslin, L. \& Ensslin, S. R. (2012). A avaliação de programas de capacitação: Um estudo de caso na administração pública. Revista de Administração Pública, 46(3), 647-675.

Umapathy, S. (1987). Current budgeting practices in U.S. industry. New York: Quorum Books.

Uyar, A. \& Bilgin, N. (2011). Budgeting practices in the Turkish hospitality industry: An exploratory survey in the Antalya region. International Journal of Hospitality Management, 30(2), 398-408.

West, D., \& Prendergast, G. P. (2009). Advertising and promotions budgeting and the role of risk. European Journal of Marketing, 43(11/12), 1457-1476.

Winata, L., \& Mia, L. (2005). Information technology and the performance effect of managers' participation in budgeting: Evidence from the hotel industry. International Journal of Hospitality Management, 24(1), 21-39.

Zonatto, V. C. S. \& Lavarda, C. E. F. (2013). Evidências dos efeitos da participação orçamentária na assimetria de informação, estresse ocupacional e desempenho no trabalho. Advances in Scientific and Applied Accounting, 6(1), 92-111. 